\title{
Escravos, roceiros e povos originários em Sant'Ana de Paranaíba: terra e liberdade nos campos do Sul de Mato Grosso (séculos XVIII e XIX)
}

Maria Celma Borges*

\begin{abstract}
Resumo: Utilizando fontes diversas (relatórios de Província, relatos monçoeiros, documentos avulsos e processos-crime), estudamos os escravos e roceiros no Sul de Mato Grosso, com enfoque para os campos de Sant'Ana de Paranaíba, no século XIX. O objetivo é analisar as relações de poder e o cotidiano vivido pelos homens e mulheres escravizados e pobres livres, sem perder de vista os detentores do poder econômico e político da região. Os povos originários tornam-se foco de análise ao se fazerem presentes, de forma intensa, por todo o Sul de Mato Grosso, por entre matas e roças, conflitos e acomodamentos. Para essa discussão, vimos a necessidade de retomar os caminhos das monções, no século XVIII, alargando o recorte temporal e a região em questão.
\end{abstract}

Palavras-chave: Escravos; Roceiros; Indígenas; Sul de Mato Grosso.

\begin{abstract}
Using different sources (Province report, interior fluvial Explorer of Brazil, Odd documents and crime process, among others), we studied the slaves and peasants in Mato Grosso, with focus on the fields of Sant'Ana de Paranaíba, in the XIX century. The aim is to analyze the power relationship and the everyday lived by those men and women slaved and free poors, without losing the owners of the economical and political powers of the region. The aboriginal people become focus of analysis when they are present, in intensive form, all over south of Mato Grosso, among jungles and plantation, conflicts and accommodation. To this argument, we saw the necessity to take back the way of the fluvial expedition to explorer the interior of Brazil in the XVIII century, widening the time cut and the region in focus.
\end{abstract}

Keywords: Slaves, Peasants; Indians; South of Mato Grosso.

\section{INTRODUÇÃO}

Para a análise do modo de vida e trabalho dos escravos, roceiros e povos originários na região de Sant'Ana de Paranaíba, no século XIX, faz-se necessário retomar o contexto da América Portuguesa, buscando indícios da presença de roças e roceiros pelo caminho das monções, no Sul de Mato Grosso, por entre os rios Grande e Pardo até os campos de Vacaria e Camapuã.

No estudo do processo de ocupação das terras e do "afazendar-se"1 por essas regiões, visamos apreender onde os homens e mulheres pobres, livres e escravizados se encontravam; quais trabalhos realizavam; como viviam; como festejavam; como resistiam à violência; que lugar lhes foi destinado e qual fora conquistado nessa paisagem que, por

\footnotetext{
* Professora da Universidade Federal de Mato Grosso do Sul. E-mail: celmaevitor@ibest.com.br. Esta pesquisa foi desenvolvida a partir de um projeto financiado pela FUNDECT/MS, entre os anos de 2009 e 2011.

${ }^{1}$ LOPES, Joaquim Francisco. Derrotas. Campo Grande: Instituto Hist. e Geograf. de Mato Grosso do Sul, 2010.
} 
vezes, parece se resumir ao boi e ao pioneiro. Nesse universo, coube analisar como as relações de poder iam sendo estabelecidas face aos povos originários, questionando como eram vistos pela administração da Província e como reagiram à tentativa de acomodá-los aos trabalhos nas fazendas. Analisaremos ainda a administração local, em diversos lugares e posições, enfatizando o modo como as relações de poder iam sendo estabelecidas, tal como o seu reverso.

Os indícios deixados por esses sujeitos ao longo da história são buscados nas fontes coletadas nos arquivos públicos de Mato Grosso e de Mato Grosso do Sul, nos relatos de viajantes, relatórios de Província, memórias, processos-crime e documentos avulsos, entre outros.

POBRES LIVRES, ESCRAVOS E POVOS ORIGINÁRIOS PELOS CAMINHOS DAS MONÇÕES NO SUL DE MATO GROSSO

Pela leitura das fontes e da bibliografia específica, é possível entender que a história da concentração fundiária na Província de Mato Grosso tem raízes profundas, fundamentadas, a princípio, nas veias auríferas, ao Norte. Percorrer o caminho que levava às minas dessa região, portanto, permite apreender as marcas que os pobres livres, escravos e povos originários deixaram num espaço de concentração de terra e de poder. Para esse fim, a obra Monções ${ }^{2}$ é leitura obrigatória por abordar os primeiros caminhos traçados em busca das minas.

Sob ordens da Coroa ou de interesses particulares, as expedições paulistas, levando trabalhadores livres e escravizados, partiam do rio Tietê, na antiga Araritaguaba, hoje Porto Feliz, enfrentando, por cerca de três mil e quinhentos quilômetros, conforme Taunay e Holanda ${ }^{3}$, corredeiras, saltos e o encontro com os povos originários.

Os responsáveis pelas monções, acompanhados de negros da terra, como guias e canoeiros, e de africanos escravizados também para o trabalho nas canoas e no transporte de mercadorias por terras e varadouros, adentravam as matas e rios até chegar às lavras de ouro, ao Norte. Nesse ínterim, se deparavam com inúmeros desafios, sendo um dos maiores o contato com os povos originários que defendiam o seu território, particularmente os Guaicuru (índios cavaleiros); os Paiaguá (índios canoeiros) e os Cayapó, que cultivavam roças e habitavam um vasto terreno que envolvia a região de Sant'Ana de Paranaíba e outras partes de Mato Grosso.

A descoberta de minas de ouro em Cuiabá se deu em 1722. Após 1738, com o surgimento de novas lavras, o fluxo populacional aumentou consideravelmente, havendo a necessidade de abrir novas estradas para as incursões terrestres, além das vias fluviais.

\footnotetext{
${ }^{2}$ HOLANDA, Sérgio Buarque de. Monções. 3. ${ }^{a}$ ed. ampl. São Paulo: Brasiliense, 1990.

${ }^{3}$ HOLANDA, S. B. Op. cit. TAUNAY, Afonso de E. Relatos Monçoeiros. São Paulo: Editora Itatiaia, 1981.
} 
Conforme Bianchini ${ }^{4}$, com a descoberta do ouro, deu-se a constituição da Capitania de Mato Grosso, sendo a região desmembrada da Capitania de São Paulo, no ano de 1748.

As expedições auríferas, na busca pelo ouro amarelo ou pela prata, contribuíram para que houvesse um desinteresse de grande parte da população em fixar moradia, pois a maioria estava à procura de riquezas advindas da mineração e não estava preocupada com o cultivo da terra e a formação de pequenas propriedades. Para muitos dos que se aventuravam pelos caminhos móveis, não interessava o estabelecimento de um polo produtor de alimentos, daí a fome ser um elemento constante em meio à vida e ao trabalho de arraiais e vilas que iam se formando ao redor do que se sonhara como terra do ouro e da riqueza "fácil".

Ao envolver grandes contingentes populacionais, esse movimento de deslocamento, particularmente nas regiões auríferas, contribuiu largamente para a expansão das fronteiras e para a preocupação com a defesa do território. Na tentativa de defesa dessas áreas, fortes e presídios foram levantados para marcar as posses portuguesas e se defender das incursões espanholas, tal como das ações dos povos originários, a exemplo do Forte de Nossa Senhora dos Prazeres de Iguatemi, no extremo Sul da Província, destruído pelos espanhóis em 1777; do Forte Príncipe da Beira (1776), na Amazônia, ao Norte; do Forte de Coimbra (1775) e do Fortim de Miranda (1797), no pantanal, na fronteira Centro-Oeste da Província. Segundo Queiroz, esses estabelecimentos "destinavam-se, de fato, a defender a posse lusa desse território, garantindo, entre outras coisas, a segurança da rota monçoeira - que, embora constantemente diminuída em sua função comercial, continuava importante para os interesses estatais [... $]^{15}$.

Em meio à economia aurífera, o trabalho de produção alimentícia cabia às populações indígenas e aos homens pobres livres e escravizados. As roças, numa quantidade bem inferior ao necessário, eram cultivadas para atender, minimamente, ao mercado consumidor das lavras e caminhos das monções. O fato de a Capitania de Mato Grosso ser reduto de produção de ouro dificultou o processo de ocupação e o povoamento do não índio, particularmente do pobre, por toda a sua extensão. Homens e mulheres que tinham cabedais - ou nem tanto - se deslocavam para a região à procura de riquezas minerais e a deixavam o mais rápido possível, sonhando retornar para a sua terra de origem. ${ }^{6}$ Com a diminuição das lavras, as pequenas propriedades tornaram-se ainda mais escassas ou se transformaram em grandes extensões de terras.

Taunay nos conta que, na busca desenfreada pelo ouro ou pelo que se chamava de "as grandezas de Cuiabá", nada fazia diminuir o afluxo dos imigrantes na segunda década do

\footnotetext{
${ }^{4}$ BIANCHINI, Odaléa da C. Deniz. A Companhia Matte Larangeira e a Ocupação da Terra do Sul de Mato Grosso (1880-1940). Campo Grande: Editora UFMS, 2000.

${ }^{5}$ QUEIROZ, Paulo Roberto Cimó. "Caminhos e fronteiras": vias de transporte no extremo oeste do Brasil. In: GOULARTI FILHO, Alcides; QUEIROZ, Paulo Roberto Cimo (Orgs). Transportes e formação regional Contribuições à história dos transportes no Brasil. Dourados: Editora UFGD, 2011.

${ }^{6} \mathrm{O}$ texto de SOUZA, Laura de Mello e. Formas provisórias de existência: a vida cotidiana nos caminhos, nas fronteiras e nas fortificações. In: SOUZA, Laura de Mello; NOVAIS, Fernando. História da vida privada no Brasil cotidiano e vida privada na América Portuguesa. São Paulo: Companhia das Letras, 1997 é bastante revelador do desejo de retornar às terras de origem.
} 
século XVIII, nem mesmo o temor da fome que rondava toda a América Portuguesa, como observou Linhares ${ }^{7}$, principalmente pelo caminho das monções, em Cuiabá, e em outros lugares de produção aurífera. Para o autor de "Relatos Monçoeiros",

\begin{abstract}
nem as mais sinistras notícias do extermínio de expedições inteiras pelos terríveis canoeiros e cavaleiros, paiaguás e guaicurus. Nem o anúncio de pestes, das carneiradas, e das temerosas fomes do Cuiabá, onde, mais de uma vez, se realiza o que a mitologia grega de simbolismo sempre poderoso, concretiza na imagem de Midas, morrendo de inanição à margem do Pactolo. ${ }^{8}$
\end{abstract}

Ainda sobre a escassez de alimentos nas viagens e, mais que isso, sobre o modo como os escravos eram vistos nas monções, chama a atenção na obra deste autor as considerações de Gervásio Leite Rebelo, secretário do Capitão-General de São Paulo, Rodrigo César de Menezes, em viagem a Cuiabá no ano de 1727. Tais observações foram feitas no varadouro de Camapuã, lugar importante para os viajantes se abastecerem de víveres para completar o restante da viagem até Cuiabá: "Caminhavam as canoas sobre carretas a que arrastavam de 20 a 30 pretos. Estes verdadeiros e miseráveis galés arrombavam as caixas e furtavam os mantimentos." Conta Taunay: "Nesta altura, comenta o secretário de Rodrigo César, é pior a perda de mantimentos do que a de um negro, sendo estes tão necessários. Antes perder um negro do que um alqueire de milho, feijão ou farinha." 9

Numa perspectiva inversa ao discurso da epopeia do colonizador ou do desbravador e/ou pioneiro, as considerações de Gervásio Leite Rebelo, destacadas por Taunay, nos mostram a presença do negro escravizado e a roça, o que permite sugerir relações de dominação e de resistência vividas pelos escravos e roceiros no confronto com a ordem privada quando do contato com os senhores e os seus mandatários, principalmente no espaço agrário, mas também no de dominação pública, a exemplo dos tribunais. Os processos-crime, abordados logo adiante neste texto, tornam-se fontes primordiais para essa reflexão.

Retomamos o caminho das monções, vasculhando pegadas que os roceiros e escravos possam ter deixado, ao imprimir a sua história no modo de vida possível, em um espaço de concentração da terra e do poder. É possível depreender a presença de roceiros na região, pelas considerações do Capitão João Antonio Cabral Camello, ao escrever, de Cuiabá, para o Padre Diogo Soares, e discorrer sobre a viagem que fez às minas de Cuiabá e Goiás, no ano de 1727.

Ao narrar o percurso pelo rio Grande, o Capitão conta que foram gastos quatro ou cinco dias entre esse curso e o rio Verde: "Abaixo da barra do Rio Verde estão dois moradores com suas roças, a primeira da parte esquerda do Rio Grande, com uma capela do

\footnotetext{
7 LINHARES, Maria Yedda Leite. História do abastecimento: uma problemática em questão (1530-1918). Brasília: Binagri, 1979.

${ }^{8}$ TAUNAY, A. Op. cit., p. 15.

${ }^{9}$ Idem, p. 74.
} 
Bom Jesus; a segunda da direita, ambas com bastante milho e feijão, que vendem como querem." 10

Se num primeiro momento as roças serviam para alimentar os viajantes que seguiam rumo às minas de Cuiabá, servindo para o fornecimento de alimentos como o milho, a mandioca, a abóbora, o feijão, entre outros produtos, ainda que a preço elevado, com o desenrolar da colonização, principalmente no século XIX, vão se tornando empecilhos para a constituição de empreendimentos privados. Exemplo disso é a tomada de terras dos posseiros e povos originários pela Companhia Matte Larangeira ${ }^{11}$, em fins do XIX e primeiras décadas do XX, no extremo Sul da Província, e a pecuária consubstanciada na grande propriedade e nos interesses alheios aos roceiros, de Norte a Sul de Mato Grosso.

A liberalidade do governo provincial, ao facilitar e mesmo incentivar a ocupação de extensas parcelas de áreas para a criação do gado, já referendava o desinteresse no fomento à pequena propriedade. Os pobres dos campos e vilarejos iam encontrando lugar naquele universo como agregados, trabalhadores de terras alheias, participantes de milícias particulares, pequenos roceiros, entre outros serviços.

O relato do presidente de Província, Major Joaquim José de Oliveira, na abertura da Assembleia Legislativa, em 3 de maio de 1849, torna-se importante para pensarmos os rumos da pecuária no Norte de Mato Grosso em meados do século XIX, situação que chegaria às terras do Sul. Conforme essa fonte, "a exportação do gado vacum tem tido algum incremento nestes últimos anos e as fazendas de criação vão substituindo os estabelecimentos de mineração"12. Sobre essa economia pastoril, com o olhar para a realidade em estudo, são interessantes as considerações de Queiroz, ao observar que

\begin{abstract}
tratava-se, por certo, de uma economia pobre e frágil, na medida em que ela se centrava na "exportação" do gado bovino magro (o qual, depois de engordado nas invernadas mineiras, seguia para o abate nos centros urbanos do Sudeste, especialmente o Rio de Janeiro). Mesmo assim, o novo povoado de Santana do Paranaíba logo se converteu no nó ideal de um novo sistema de comunicações, que começou a tomar forma ainda na primeira metade do século XIX. ${ }^{13}$
\end{abstract}

Ainda que de início de forma "pobre e frágil", a formação de pastagens no meio rural, derivando na expulsão, morte ou aldeamento dos povos originários, assim como na expropriação dos antigos moradores -principalmente daqueles que não tinham senão o seu trabalho nas lavouras -, apresentou uma situação que caracterizou, de forma bastante intensa, as relações de trabalho e o modo de vida por aquelas paragens.

\footnotetext{
${ }^{10}$ NOTÍCIAS PRÁTICAS. Das minas do Cuiabá e Goyazes, na Capitania de S. Paulo e Cuiabá, que dá ao Rev. Padre Diogo Soares, o Capitão João Antonio Cabral Camello, sobre a viagem que fez às Minas do Cuiabá no anno de 1727. In: Revista Trimestral de História e Geographia ou Jornal do Instituto Histórico Geographico Brasileiro. Tomo Quarto, n. 16, Janeiro de 1843. Rio de Janeiro. Imprensa Americana de J. P. da Costa, 1843.

${ }^{11}$ Sobre a Matte Larangeira, consultar a obra de BIANCHINI, O. Op. cit.

${ }^{12}$ RELATÓRIO do Presidente da Província de Mato-Grosso o Major Doutor Joaquim José de Oliveira na abertura da Assembleia Legislativa Provincial, em 03 de maio de 1849. Rio de Janeiro: Typ. Imp. e Const. de J. Villeneuve e Comp. 1850, p. 15. http://www.crl.edu/pt-br/brazil/provincial/mato_grosso.

${ }^{13}$ QUEIROZ, op. cit.
} 
Para a análise desse cenário, é preciso percorrer o caminho das monções no século XVIII, buscando as impressões de viagem e os sujeitos que nos interessam no interior das narrativas. O tópico a seguir tenta fazer esse exercício no sentido de encontrar os agentes centrais da pesquisa: escravizados, pobres livres e povos originários.

\section{IMPRESSÕES DE VIAGEM PELOS CAMINHOS DAS MONÇÕES}

Na discussão dos caminhos das monções é interessante retomar o relato de viagem do capitão de fragata, Francisco José de Lacerda e Almeida ${ }^{14}$, pelas Capitanias do Pará, Rio Negro, Mato Grosso, Cuiabá e São Paulo entre os anos de 1780 e 1790 . Ainda que não seja especificamente uma viagem monçoeira, pois a preocupação do capitão era fazer um levantamento hidrográfico, o relato aponta aspectos importantes da rota das monções.

Depois de percorrer as capitanias do Pará e Rio Negro, Almeida chegou a Vila Bela, Mato Grosso, partindo dessa localidade em 13 de setembro de 1786 em direção a Cuiabá, onde aportou no dia 29. Demorou-se por cerca de quinze dias até preparar-se para a viagem rumo à Capitania de São Paulo. O retorno para essa capitania é o caminho que nos interessa, de forma particular, por tratar diretamente da região em estudo.

Segundo o capitão Almeida, trabalhadores o acompanharam em um batelão, adquirido para esse fim, já "que tantos eram precisos para as vareações nos saltos"15. A tripulação era composta de vinte e oito homens:

[...] valorosos, e destemidos, mas desconfiados, e incivis por educação e ofício, e próximo a atravessar um sertão vastíssimo habitado por diferentes nações de gentios valorosos, e indômitos, e que por muitas vezes tem feito grandes estragos em vidas e fazendas. ${ }^{16}$

O autor se restringiu à essa explicação para falar de sua tripulação. Quiçá esses trabalhadores, outros pobres livres, os escravos e os povos originários, despertassem o interesse e o desejo da narrativa em Almeida, tal como a paisagem, ao olhar para a flora e para a fauna.

Em nota, Almeida destacou a importância da fundação da Vila de Sorocaba, na Capitania de São Paulo, no século XVIII, para alimentar o comércio de Cuiabá, já que os negociantes de fora, ao não serem obrigados a ir até Araritaguaba para terem acesso às canoas, evitariam as cachoeiras da foz do rio Sorocaba. Essa povoação era vista então como "necessária para que se façam canoas, e para haver gente nesse único varador". Observou

\footnotetext{
${ }^{14}$ ALMEIDA, Francisco José de Lacerda. Diário da viagem de Villa Bella para S. Paulo. Ano de 1788. In: Diários de Viagem de Francisco José de Lacerda e Almeida pelas capitanias do Pará, Rio Negro, Mato Grosso, Cuiabá e São Paulo nos anos de 1780 e 1790. Biblioteca Digital da Câmara dos Deputados. Centro de Documentação e Informação. Coordenação de Biblioteca. http://bd.camara.gov.br/bd/handle/bdcamara/1941. Acesso em: 05 dez. 2011.

${ }^{15}$ Idem, p. 64.

${ }^{16}$ Idem, p. 65.
} 
ainda: "Bem se sabe a necessidade que esta Capitania tem do ouro de Cuiabá e se não deve conservar fechada esta nova porta." ${ }^{17}$

Discorrendo sobre as terras de Mato Grosso, o autor narrou:

[...] dão com usura os legumes, o arroz, a cana, de que faz ótimo açúcar, o milho, que reduzido à farinha serve de pão, e com ele se cevam os muitos porcos que há de muito bom sabor; o café, o anil, que naturalmente nasce; a laranja, que por muito doce causa sede, e cujas árvores em todo o ano tem flor, fruto verde e maduro; a banana, bem como em outras partes da América, a exceção das partes mais Austrais, em que a geada as não deixa produzir. ${ }^{18}$

Mesmo diante de toda a abundância de alimentos que a terra poderia propiciar, o que fazia de Mato Grosso realmente a riqueza do país, no seu entender,

[...] são as boas minas de ouro que tem, e de subido quilate: e se não fosse o avultado preço do aço, ferro e escravos, dos quais morre uma grande parte pela malignidade do clima, seriam os mineiros mais ricos, e a Fazenda Real teria maiores rendimentos, pois na verdade são as minas mais rendosas que presentemente temos, e o único lucro que de semelhante terra se pode tirar por se não poderem transportar os seus efeitos para os portos do mar: este o motivo por que os lavradores se contentam com a cultura do que somente pode ter consumo na terra, atendendo muito à qualidade e quantidade dos efeitos que para esse fim devem semear. ${ }^{19}$

O que se percebe nesse relato, tal como em vários outros encontrados na pesquisa - a exemplo dos Relatos Monçoeiros -, é o fato de que, ao narrar o percurso e as suas preocupações, a paisagem era muito mais interessante que os próprios sujeitos, como se observa a seguir:

Retrocedendo de várias veredas falsas, que segui, naveguei $2 \frac{1}{2}$ léguas por entre os água-pés do pantanal, que são umas ervas aquáticas, que se entrelaçam umas com outras de forma que muitas vezes é necessário abrir caminho com facões; e cuja flor, estando aberta, forma a mais bela e regular bandeja circular, sendo as maiores que vi de três palmos de diâmetro pouco mais ou menos. ${ }^{20}$

A não ser aqueles apontamentos em que os povos originários comumente são apresentados como "ervas daninhas", quanto aos pobres livres e escravizados os dados são bem menos expressivos, quase que inexistentes. A natureza é exuberante, os animais, insetos e plantas encontrados no ar, rio e terra, em sua diversidade, vão pululando pelas páginas dos diários. Onças, pássaros, caças e frutas silvestres permeiam as narrativas, recheando o espaço natural de belezas e intempéries. Os povos originários ora são vistos como edênicos, ora como demoníacos, mas sobre os camaradas e escravizados, vez ou outra, encontramos parcos indícios, misturando-os às "cenas de viagem", como se não

\footnotetext{
${ }^{17}$ Idem, p. 60.

${ }^{18}$ Idem, p. 64.

${ }^{19}$ Idem.

${ }^{20}$ Idem, p. 68.
} 
tivessem rosto, muito menos história. Essa é uma leitura comum ao olhar de grande parte daqueles que comandavam as expedições realizadas nos séculos XVIII e XIX, no conhecimento da flora e da fauna, ou mesmo na busca de metais preciosos.

No trabalho de Almeida, em rara passagem em que os pobres livres e escravizados aparecem, há a evidência da presença de negros libertos e escravizados utilizados no apresamento dos Cayapó na região de Camapuã, o que desvela as contradições dessa realidade:

\begin{abstract}
Há três para quatro anos que tendo esse gentio insultado no Cuxim a uns comerciantes que navegavam para o Cuiabá, o administrador da fazenda para os intimidar mandou um destacamento composto de alguns mulatos libertos e de outros escravos da fazenda, homens na verdade capazes de se lhes confiar qualquer empresa, em que se deva ter valor e intrepidez, os quais no fim de alguns dias os encontraram, (e talvez aos inocentes) e fizeram uma boa presa de rapazes e de mulheres de toda a idade, e os conduziram à fazenda, onde os vi falando português, alegres e pacíficos, depois de terem tentado a fuga por duas vezes inutilmente, pois foram seguidos pelo rasto, e apanhados. Vi duas mulheres velhíssimas, mas tão fortes que na dita fuga foram apanhadas carregando cada uma às costas o seu rapaz de cinco para seis anos. ${ }^{21}$
\end{abstract}

Esse trecho demonstra o modo como se desenhara o processo de colonização pelo Sul de Mato Grosso, em terras da fazenda de Camapuã, conhecida na historiografia como varadouro de grande importância no percurso das monções, pois lugar em que os viajantes, após meses de travessia, se abasteciam de mercadorias e descansavam para chegar às minas de Cuiabá. Em Camapuã, semelhante ao que ocorria em outras partes do Império, a dura realidade se evidencia ao encontrarmos a situação de escravos e libertos contribuindo para aprisionar povos originários. Não somente indígenas tiveram o papel na captura de negros escravizados fugidos de engenhos, fazendas e sítios, principalmente para os quilombos, mas também escravos negros e libertos contribuíram para o aprisionamento dos povos originários, como se depreende da fonte.

Essa é uma das grandes ambiguidades do processo de ocupação da terra e de apresamento da mão de obra indígena, tal como uma das faces da violência da escravidão negra, ao serem os negros cativos obrigados a sair à captura de homens, mulheres e crianças indígenas. $O$ trabalho de libertos, na condição de camaradas, servindo como instrumento de poder para os proprietários de terras, comerciantes e representantes da administração, também demonstra o peso da colonização e um dos lugares ocupados por esses homens nesse universo de mandos e desmandos.

$\mathrm{Na}$ análise das narrativas de viagem de São Paulo a Cuiabá, ou pelo caminho inverso, aqueles que aparecem no comando das incursões quase sempre são sujeitos advindos da elite, acostumados às relações de dominação e de poder, em que homens e mulheres pobres, livres e escravizados são vistos como mais uma peça a engrenar-se nas ordens que emanam do comando, seja no interior das embarcações, ou pelos varadouros e pousos, ao servirem para fazer a travessia por água e terra, transportar batelões, cargas e

\footnotetext{
${ }^{21}$ Idem, p. 75.
} 
canoas, realizando os trabalhos mais adversos, aos quais os comandantes, com certeza, não fariam.

Numa outra passagem, Almeida narra a alegria dos vinte e oito camaradas ao se depararem com o rio Tietê, momento em que comemoram, com gritos de entusiasmo e muita aguardente, a chegada a que o autor denomina como o seu "país natalício", um lugar mais próximo ao lar, depois das muitas intempéries vividas pelos rios de Mato Grosso, do Norte ao Sul. O modo como observa a cena denuncia a sua leitura sobre os trabalhadores que compunham essa expedição:

Pelas $3 \mathrm{~h}$ da tarde passei fronteando a foz do Rio Sucuriú, que vem do ocidente e cuja largura me pareceu de 50 braças. Pernoitei na barra do Tietê, que tem de largura 70 braças. Pela alegria que tiveram os camaradas de chegarem ao rio, que banha seu país natalício, se enfureceram, e entre grandes gritarias e vivas gastaram-me em salvas frasco e meio de pólvora, e uns poucos de aguardente. Talvez que a alegria fosse fingida, e servisse de pretexto para subir a frasqueira a riba. $^{22}$

Essas são apenas algumas impressões do relato desse viajante, mas que possibilitam entender uma parte da história dos pobres livres, escravos e povos originários pelos caminhos das monções nos campos do Sul de Mato Grosso, sob o olhar daqueles que comandavam as incursões. São brechas que encontramos dentro da documentação oficial, as quais possibilitam entrever ações e sujeitos que, de outro modo, continuariam invisíveis não fosse por essas frestas e pelo desejo de encontrá-las.

\section{OS POVOS ORIGINÁRIOS A CRUZAR OS CAMINHOS DAS MONÇÕES}

Ao trabalharmos as fontes coletadas nos arquivos de Mato Grosso e Mato Grosso do Sul, encontramos as evidências da história do Sul de Mato Grosso, no que concerne à economia agropastoril e à administração, porém, mais que isso, nos interessam os sujeitos nelas envoltos ou às suas margens. Buscamos então percorrer os passos dos homens e mulheres pobres em terras de Sant'Ana de Paranaíba e arredores, desde fins dos anos de 1820, mas principalmente após 1830, num marco delimitado pela documentação. No Registro de Correspondência Oficial ${ }^{23}$, do período de 1838-1839, enviada pelo presidente da Província de Mato Grosso, José Antonio Pimenta Bueno, aos oficiais do interior, é possível encontrar as marcas de uma história que vai se constituindo ao longo das décadas pela presença das chamadas famílias pioneiras, cujos sobrenomes aparecem em relevo.

Se o olhar estiver voltado para as entrelinhas da documentação, é possível encontrar aí os povos originários, tal como os pobres livres e escravos, nos interstícios de uma ordem que parecia emanar e se restringir aos pioneiros. As brechas, propiciadas pela

\footnotetext{
${ }^{22}$ Idem, p. 80.

${ }^{23}$ DOC. 056, Est. 05. Registro de Correspondência Oficial com o interior da Província. Arquivo Público do Estado de Mato Grosso, Cuiabá - MT (1838-1839).
} 
análise das fontes, nos revelam como essas outras histórias vão se descortinando paralelamente à do pioneiro, por vezes a ele se misturando, pelo contexto do XIX.

No documento relacionado anteriormente, chama a atenção o destaque para a estrada do Piquiri, que ligaria a Província de Goiás à de São Paulo, passando pelas terras de Sant'Ana de Paranaíba. Esse empreendimento foi bastante incentivado pelo governo da Província de Mato Grosso desde os anos de 1830, devido ao interesse de que essa via se tornasse o canal de comércio e comunicação entre as províncias de Goiás, Minas Gerais e São Paulo.

Inúmeras referências podem ser encontradas nos Relatórios de Província e documentos avulsos sobre o desejo de construção dessa estrada. A preocupação do governo de Mato Grosso estava em transformá-la em caminho que pudesse oferecer "um seguro e livre trânsito ao comércio" 24 . Pelos seus traçados, são várias as referências ao enfrentamento entre os povos originários e transeuntes, tal como com aqueles que desejassem se fixar como moradores pelas margens dessa via.

Quase dez anos após o início das primeiras obras para a construção dessa estrada para a Província de Goiás, no ano de 1847, o presidente da Província, João Crispiano Soares, chamou a atenção para o fato de que se achava ainda despovoada, "pois que alguns dos moradores, que em outro tempo por ali existiram, abandonaram suas habitações, afugentados pelas ameaças dos índios bravios que costumam infestá-las" ${ }^{25}$.

Os Coroado e Cayapó integram os relatos dos viajantes e dos presidentes de Província por todo o século XIX. O trecho anterior ilustra essa questão ao apontar para a presença desses povos na estrada do Piquiri nos meados deste século. O relatório ainda apresenta as ordens do governo para que bandeiras fossem enviadas a fim de conter ou, em outras palavras, exterminar essas populações, vistas como "embaraços" ao encaminhamento das obras. Podemos supor, diante desse cenário, a mortandade de indígenas para o encaminhamento desse empreendimento provincial.

Com um olhar quase incomum aos que escreveram sobre os povos originários no contexto do XIX e início do XX, Miguel Arrojado Ribeiro Lisboa -ao discorrer, em 1908, sobre a geologia, a indústria mineral, o clima, a vegetação, o solo agrícola e a indústria pastoril no Oeste de São Paulo e Sul de Mato Grosso -, nos dá elementos para entendermos alguns desses povos em Mato Grosso. Nas páginas finais de seu trabalho, Lisboa observa:

Até 1800 ainda eram as margens do Paraná muito povoadas de índios mesmo no Estado de Mato-Grosso. A esse tempo ainda subiam eles o rio Pardo até transporem o alto divisor, passando as águas do Coxim e Taquary. Não raramente flagelavam a população sertaneja. Hoje as condições estão inteiramente mudadas.

\footnotetext{
${ }^{24}$ Idem.

${ }^{25}$ FALLA dirigida pelo Excelentíssimo Senhor Doutor João Crispiano Soares, atual Presidente da Província de Mato Grosso à Assembleia Legislativa no ato de sua instalação em 03 de maio de 1847. Cuyabá: Tipographia Provincial, 1847, p. 18.
} 
Índios em seu estado primitivo, ainda selvagens, existem somente em uma pequena secção do Paraná, entre a barra do Rio Pardo e a do Samambaia. ${ }^{26}$

Dando continuidade à reflexão sobre esses povos originários, observa que foram erroneamente chamados de "Xavantes". Quanto ao olhar que os não índios estabeleceram sobre eles, destacou:

São considerados na zona como fracos e medrosos, embora reputados mestres no roubo. Tem sido muito perseguidos e sacrificados. Uma ou outra vez eles deixam o rio Pardo e sobem o Paraná à caça de embarcações e utensílios. Um pequeno bando desses índios esteve em contato recentemente com a turma exploradora do Rio do Peixe da Comissão Geográfica e Geológica de São Paulo. Ainda dois indivíduos da mesma tribo foram encontrados pela turma do Paraná da mesma Comissão e deram a fala. ${ }^{27}$

Quanto a um desses encontros e à referência à região em estudo, chamam a atenção, um século antes, em 1810, as anotações de João Ferreira de Oliveira Bueno ${ }^{28}$, tesoureiro-mor da Sé de São Paulo, narrando a sua viagem com o irmão, pelo rio Paraná. Tais registros possibilitam entendermos como a "civilização" contribuiu para a dizimação desses povos, contribuindo ainda para entrever a presença dos "mulatos", negros escravizados, que acompanhavam essas incursões pelo rio Paraná à procura do "bárbaro":

De manhã naveguei com duas canoas pelo Paraná abaixo a ver se encontrava os índios, e cheguei à barra do Rio Sucuriú que deságua no Paraná da parte ocidental; e divisando muito abaixo uma fumaça na margem oriental, mandei virar as canoas para aquele sítio, passando pelo Jupiá, que é um recife de pedras, que nasce de uma e outra margem para a foz do rio, ficando um pequeno boqueirão, por onde correm as águas com imensa velocidade, fazendo muitos redemoinhos, sendo necessário passarem as canoas com cordas na popa e proa, indo as pessoas que as levavam, por cima das pedras, afim de não serem submergidas pelos ditos redemoinhos, e parei em uma ilha de areia e pedra, defronte de lugar onde tinha divisado a fumaça, e nela demorei-me algum tempo, mandando tocar a buzina, a ver se se mostravam os bárbaros, o que não aconteceu: inferindo que era alguma partida ou tribo feroz que ali se achava; e vendo baldada a minha diligência, voltei para o meu quartel, chegando às nove horas da noite, com projeto de ir no dia seguinte pelo Paraná acima até o Salto do Urubupungá e depois que cheguei soube de uns mulatos, meus escravos, que tinham ido pelo Paraná acima, terem encontrado os selvagens em uma e outra margem do rio, de cujo encontro assustados voltaram com toda a celeridade. ${ }^{29}$

O processo de violência impetrado pelo colonizador aos indígenas pode ser apreendido de forma mais pontuada nas entrelinhas desse texto, particularmente na

\footnotetext{
${ }^{26}$ LISBOA, Miguel Arrojado Ribeiro. Oeste de São Paulo, Sul de Mato Grosso. Campo Grande: Editora Alvorada, 2010, p. 216.

${ }^{27}$ Idem, p. 217.

${ }^{28}$ SIMPLES narração da viagem que fez ao Rio Paraná, João Ferreira de Oliveira Boeno, tesoureiro-mor da Sé de S. Paulo, em 1810, copiada de um manuscrito oferecido ao Instituto pelo sócio correspondente, o Sr. José Domingues de A. Moncorvo. In: Revista do Instituto Histórico e Geográfico Brasileiro, Tomo I, 1839. Rio de Janeiro: Imprensa Nacional, 1908.

${ }^{29}$ Idem, p. 144.
} 
segunda narrativa, apresentada abaixo, quando Bueno discorre sobre o modo de vida desses povos no início do século XIX, levando-nos a entender como se tornaram reféns dos "mimos" e da "civilização":

Dia 28 - Amanheceu chovendo, e este acontecimento obstou ao meu projeto de ir ao Salto de Urubupungá; porém meu irmão, o capitão Miguel Ferreira de Oliveira Bueno, por divertir-se foi à barra do Rio Tietê, que fica próxima à ilha onde estava aquartelado, e nela encontrou na margem oriental do Paraná três selvagens que pescavam, os quais nenhum sobressalto tiveram, antes convieram em vir na canoa ao meu quartel, revestindo-se de tanta confiança e candura, que no embarque lançaram na praia seus arcos e flechas, e até uma faca velha que tinham; mas meu irmão mandou embarcar tudo, e assim os trouxe ao meu abarracamento, onde os tratei com todo o agasalho e urbanidade; e depois que lhes mandei dar de comer, dei-lhes facas, fumo, farinha, feijão, sal, açúcar, e até mandei-lhes cortar os cabelos, e tornei a mandá-los por no mesmo lugar em que tinham sido encontrados, rogando-lhes que dissessem aos seus chefes que viessem ao meu quartel, porque queria vê-los e mimoseá-los. ${ }^{30}$

Avançando quase cem anos da exposição de Bueno, retomamos o texto de Lisboa de 1910, ao narrar sobre os Terena e a sua presença no traçado da estrada de ferro Noroeste do Brasil, no Pantanal, os quais ocupavam os vales dos rios Aquidauana e Miranda, no Sul de Mato Grosso, estendendo-se até o rio Taquary. Sobre esses povos, observou o autor:

Na sua nova situação de civilizados eles sofrem o domínio brutal da nossa raça. 0 trabalhador rural aí, o que equivale dizer - o Tereno -, vive sobre o jugo de uma dívida insolvável, contraída ao iniciar a sua carreira e que aumenta-se sucessivamente, o que o põe à inteira direção do patrão. Este por um costume na zona, que tem mais força que a lei, tem o direito de manter o trabalhador ao seu serviço enquanto aquela dívida não estiver saldada e como nem sempre a paciência ou a conveniência dos patrões estão por isso, há um constante comércio de dívidas. Compra-se o débito e transfere-se o trabalhador para uma nova propriedade, no que ele geralmente aquiesce mansamente. Esta mesma organização do trabalho prevalece no sul do Estado e principalmente no Norte da República do Paraguay. ${ }^{31}$

As considerações de Lisboa revelam uma prática comum dos grandes proprietários de terras no Sul de Mato Grosso pelo contexto do XIX e XX, ao esconderem a escravidão pelo trabalho forçado dos povos indígenas em fazendas, sendo essa forma de violência associada ainda à escravidão por dívidas. Essa questão nos leva a outra, apontada por Campestrini, ao apresentar um documento da terceira década do século XIX sobre a preocupação do governo provincial de "fixar e aculturar os Caiapó" ${ }^{32}$, inserindo-os em fazendas de criação de gado na região de Sant'Ana de Paranaíba. Essa informação pode ser encontrada no texto da

\footnotetext{
${ }^{30}$ Idem.

${ }^{31}$ LISBOA, Op. cit., p. 18. Grifo do autor.

32 CAMPESTRINI, Hildebrando. Santana do Paranaíba: De 1700 a 2002. 2.a ed. Campo Grande: Instituto Histórico e Geográfico de Mato Grosso do Sul, 2002, p. 18.
} 
lei de criação das Freguesias do Piquiri e de Paranaíba, em abril de 1838, consultada por Campestrini:

O governo fará estabelecer por conta do cofre provincial no lugar junto a uma das três freguesias que melhores circunstâncias ofereça uma fazenda de criação de gado vacum e cavalar, que irá aumentando à proporção do grau de prosperidade que for prometendo; o serviço dela será feito pelos índios Caiapós, admitindo-se a bem deles somente os demais trabalhadores, cujos serviços indispensáveis não possam ser supridos por aqueles. ${ }^{33}$

Tais fontes revelam o lugar ocupado por esses povos nas práticas e no imaginário da administração provincial e de grande parte dos habitantes do lugar nos séculos XIX e XX. Os processos criminais oitocentistas consultados envolvendo pobres livres são recheados de nomes que nos levam à origem indígena, o que sugere o modo como foram incorporados pelos interesses públicos e privados à denominada "civilização".

No tempo presente, as populações que sobreviveram à barbárie da chamada "civilização" reivindicam o direito ao território onde estão enterrados os seus ancestrais, e se deparam, tal como na Colônia e no Império, com a violência privada, ancorada na ineficiência ou mesmo na indiferença das políticas públicas, as quais, costumeiramente, ignoram a necessidade da defesa do direito desses povos, prevalecendo os interesses privados.

\section{RELAÇÕES DE PODER EM TERRAS DE SANT'ANA - ENTRE “TRONCOS" E DESMANDOS...}

Como sugeriu Moura e Camargo ${ }^{34}$, semelhante às fontes por nós analisadas, trabalhando pelas roças, pelos teares, fazendo os serviços domésticos da cozinha, no lavar, passar, arrumar, servindo de corpo armado na constituição de milícias dos proprietários de terras na região, entre outras atividades, é possível encontrar a presença escrava de homens, mulheres e crianças pelas terras de Paranaíba. Não se pode negar a importância da escravidão por essas localidades meridionais de Mato Grosso, como também sugeria Brazil $^{35}$, em um dos primeiros trabalhos sobre a escravidão no Sul da Província.

A pesquisa de Moura traz inúmeras fontes que demonstram a importância dos estudos sobre a escravidão no Sul de Mato Grosso. O seu olhar se volta para várias localidades dessa região, possibilitando entender o quanto a escravidão esteve impregnada no modo de vida dos sujeitos, de Corumbá à Sant'Ana de Paranaíba, não sendo possível negar essa história. No arrolar das fontes, esta autora apresenta os escravos por uma

\footnotetext{
${ }^{33}$ Apud CAMPESTRINI, 2002, p. 33.

${ }^{34}$ MOURA, Zilda A. Cativos nas terras dos Pantanais: escravidão e resistência no sul de Mato Grosso - séculos XVIII e XIX. Passo Fundo: Ed. UPF, 2008. CAMARGO, Isabel Camilo de. O Sertão de Santana de Paranaíba: um perfil da sociedade pastoril-escravista no Sul do Antigo Mato Grosso (1830-1888). Dissertação (Mestrado em História). Universidade Federal da Grande Dourados, 2010.

${ }^{35}$ BRAZIL, Maria do Carmo. Fronteira negra - Dominação, violência e resistência escrava em Mato Grosso 17181888. Rio Grande do Sul: Universidade de Passo Fundo, 2002.
} 
infinidade de lugares e de situações: na lida com o gado; no cuidado com as roças de milho, feijão, mandioca; nos afazeres domésticos e em muitas outras atividades.

Nessa perspectiva de "fazer-se" outras histórias, uma das fontes que nos chamou atenção refere-se a um documento enviado ao Chefe de Polícia de Sant'Ana, emitido pelo Palácio do Governo de Mato Grosso, no ano de 1849. Nesse documento, o presidente da Província ordenava: "Faça queimar o tronco que ali serve de prisão pública, por ser um instrumento de pena cruel abolido pela Constituição." ${ }^{36}$

Conforme esse documento, havia um "tronco" na Freguesia de Paranaíba para servir como lugar de "correção pública". Um lugar, em outras palavras, de marcada e efetiva violência, na medida em que sabemos, historicamente, o significado dos troncos e pelourinhos na vida dos homens e mulheres escravizados e pobres livres, muitos condenados a açoite e, no caso dos escravos, até mesmo à pena de morte.

Para aqueles que eram considerados infratores aos olhos da lei, o tronco servia de "exemplo". Esse instrumento de punição e castigo, ao ser colocado em lugar público, servindo como "prisão pública", demonstra as agruras da escravidão e os moldes da Justiça, dando subsídios para entendermos as semelhanças entre o que ocorria no Sul de Mato Grosso e no restante do Império.

De certo que a solicitação de fim ao espaço de arbítrio deve ter se dado por parte de alguns dos moradores de Sant'Ana de Paranaíba. Isso é muito interessante, pois possibilita entender as descontinuidades da ordem e as suas dissonâncias nas mais distantes localidades do Império. Centenas de quilômetros separavam Cuiabá de Sant'Ana, mas isso não impedia que a administração mantivesse o seu olhar que se queria vigilante, mesmo que se saiba dos limites da lei, já que a sua representação comumente era a do próprio arbítrio.

As memórias apresentadas por Justiniano Augusto de Salles Fleury - membro da família do padre Fleury, um dos mais destacados nomes de Sant'Ana - publicadas pelo jornal Republicano, de Cuiabá, em 1895, nos dão uma informação importante sobre essa prisão:

\begin{abstract}
Seria de prisão pública uma casa particular, onde via-se um grande tronco de madeira de peso, e pendentes a um lado uma tesoura e uma grande palmatória. Gozavam as autoridades de muito respeito e a sua ação era eficaz: a prisão em tronco e o castigo de bolos produziam tão bons efeitos, que naqueles tempos não se atrevia o assassino a dar um passeio a sede do distrito. O crime de morte era raríssimo, e não se viam vadios ou vagabundos. ${ }^{37}$
\end{abstract}

Semelhante ao exercício de análise de qualquer fonte, é preciso indagar sobre cada linha desse documento, já que enuncia, de forma desnudada, o olhar da elite interessado na exposição de um cenário em que a paz era o imperativo, numa afirmativa inversa ao que vimos encontrando no contato com outras fontes. Os processos-crime nos mostram o quanto era comum o crime de morte e os conflitos em Sant'Ana.

\footnotetext{
${ }^{36}$ DOC. 102. E. 06. Correspondência entre esta Província e os juízes de Direito municipais, chefes de Polícia, Delegados e Subdelegados (1848-1849). Arquivo Público do Estado de Mato Grosso, Cuiabá.

${ }^{37}$ Apud CAMARGO, 2010, p. 224.
} 
As fontes coletadas no Arquivo Público de Cuiabá, ao apresentarem embates entre presidentes da Província e representantes do poder público em Sant'Ana, possibilitam, também, a compreensão das relações de poder e conflitos na Freguesia de Paranaíba. Esses embates se materializaram particularmente nas relações entre Augusto Leverger, presidente, e José Garcial Leal, intendente, na década de 1850.

Em correspondência enviada em 1851 ao juiz de paz da Freguesia de Paranaíba, José Garcia Leal, o presidente da Província, Augusto Leverger, critica a cobrança excessiva de impostos, o que estaria impedindo o crescimento da povoação. A fonte sugere que chegou aos ouvidos do presidente a cobrança abusiva de sisas por parte de José Garcia Leal, o que levaria os moradores à "venda de suas cabanas". Contrapondo-se a isso, Leverger orienta que seja dada a isenção, por vinte anos, do pagamento de todos os direitos provinciais. ${ }^{38}$

Nesse mesmo ano, em 17 de junho, chama atenção a tentativa do presidente de impor limites aos poderes de Garcia Leal, particularmente no caso do agente dos Correios. A trama envolve Joaquim Lemos da Silva, demitido dos Correios por Garcia Leal, que nomeou em seu lugar José Rodrigues Anacleto, seu cunhado.

O documento enviado pelo presidente da Província ao ajudante da Agência de Correios de Sant'Ana deixa entrever que o caso não deveria ter ocorrido, ordenando que "tal demissão e nomeação fora menos regular, pois que assim uma como a outra é da competência do governo Imperial"39. O documento observa, porém, que "por ser incompatível o exercício de ajudante da administração do Correio com o de Juiz de Paz à vista do aviso do Ministério do Império sob n.143 de 26 de novembro de 1846, deve Vm. deixar este último cargo".

Essa fonte apresenta a disputa de poderes em Paranaíba, ao deixar claro que estava em jogo uma rivalidade entre o ajudante da agência de Correios, Joaquim Lemos da Silva ${ }^{40}$, e o Juiz de Paz, que também era o responsável pelos Correios. A correspondência aponta para

\footnotetext{
${ }^{38}$ DOC. 106, E. 06 - Registro de Correspondência oficial entre a Província e as Câmaras municipais, paróquias e bispos. (1849-1852). Arquivo Público do Estado de Mato Grosso, Cuiabá.

39 Idem, p. 122

${ }^{40}$ A informação que temos deriva das memórias de Sá Carvalho, ao observar a composição da primeira Câmara Municipal de Sant'Ana de Paranaíba, no ano de 1859, e constar o nome deste personagem, junto ao de “capitão José Garcia Leal, Sebastião José Ruiz de Queiróz, Martin Gabriel de Melo Taques, José Alves dos Santos, major Jesuíno Joaquim Guimarães e padre Mariano José Verigal Pena, que era coadjutor do padre Fleury" (Apud CAMPESTRINI, 2000, p. 43). Outra informação deriva do Inventário de sua esposa, Eufrásia Lemos da Silva, realizado no ano de 1870. In: Arquivo do Tribunal de Justiça de Mato Grosso do Sul. Processos Cíveis da Comarca de Paranaíba. Caixa 05, n. 08 - 1870: Inventário e Partilha - Inventariante: Joaquim Lemos da Silva - Inventariada: Eufrásia Lemos da Silva. Nesse documento, encontramos dados de que o "Capitão Joaquim Lemos da Silva", quando da elaboração desse inventário, encontrava-se em situação econômica bastante desfavorável, haja vista as suas dívidas passivas serem muito maiores que os bens arrolados. 0 documento também nos informa que o capitão ficara com quatro filhos, com idade de 21 a 04 anos (Leopoldina, 21 anos; Pedro, 15 anos; Herinda (?), 12 anos e Sebastião, 04 anos). É interessante observar que nos bens móveis, afora móveis velhos, utensílios de prata e cobre, são arrolados "60 livros de direito e outros, no valor de 120.000 réis". Esta última informação somada à de Giraldin (1997, p. 104), de que o capitão escrevera "um pequeno texto sobre a história de Santana do Paranaíba", em que incluía a história dos Cayapó, inclusive com a apresentação de um “Vocabulário Cayapó de Santana do Paranaíba” (1997, p. 169 a 171), demonstra a ilustração desse sujeito.
} 
- acúmulo de cargos e de poderes de Garcia Leal, tal como para o papel da administração provincial na tentativa, ao menos aparente, de minimizar os conflitos e abusos de poder.

Outra fonte reveladora dos desmandos de José Garcia Leal diz respeito à correspondência destinada a ele sobre a questão do diretor da aldeia dos índios que habitavam as imediações da Freguesia de Sant'Ana de Paranaíba. Esse documento refere-se à necessidade de que seja revisto um mandado expedido, em 23 de outubro, para que o morador "Antonio Luiz com toda a sua família" se retirasse " 5 e mais léguas da dita Aldeia dos Índios". Como represália à essa ação, o presidente da Província, Augusto Leverger, ordenou:

[...] deve abster-se de semelhante procedimento para o que não está autorizado, pois nem esta Presidência ainda nomeou Diretor para a mesma aldeia, nem o distrito dela foi até agora demarcado, aguardando o Presidente para dar últimas providências a este respeito. $^{41}$

Um documento de Augusto Leverger, enviado ao Chefe de Polícia da Província, em 1. de setembro de 1855 , deixava entender a mesma preocupação do documento anterior, qual seja, a tentativa de controle das arbitrariedades do dito "pioneiro" e dos que estavam sob sua proteção. E mais, enunciava a violência desmedida nas ações de Garcia Leal e dos que estavam à sua volta:

Cartas particulares de junho, julho e agosto inspiraram-me receios acerca da tranquilidade pública na Freguesia de Sant'Ana do Paranaíba, onde, segundo me referem, cometeram-se vários assassínios que ficaram impunes, e entre outros os de Antonio Ferreira e de seu filho Fidélis. Tudo o que posso depreender dessas cartas é que atribui-se o deplorável estado da dita Freguesia a José Garcia Leal que, dizem, intimida as autoridades e protege os fascínoras, em cujo número fazem menção de dois homens pardos de nome Jeronimo, e Francisco Coelho, camaradas ou capangas do referido Leal. Indicam-me com idôneos para servir aos cargos policiais os seguintes indivíduos Joaquim de Oliveira Simões, Francisco Garcia Leal, Manoel Garcia Leal e José Coelho Paim. Este último já é o suplente do subdelegado. Não julgo conveniente demitir os outros sem haver motivo suficiente, e em todo o caso, entendo que a ser verdade o que dizem de José Garcia Leal, seria impróbico e imoral nomear irmãos e sobrinhos desse homem, sendo de apreciar que sejam minimamente indulgentes, ou injustamente infindos, se, como suponho, a paixão ou o interesse quebrar os laços de parentesco que os une. Cumpre que V. S. procure pelos meios de seu alcance, suprir no vago das informações aferidas, e dê as convenientes providências que não me podem ocorrer no lugar e na posição em que me acho. E se se tornar precisa a ida de V. S. aquela Freguesia, pode e deve partir independentemente de outra ordem minha, deixando a polícia da capital a cargo do respectivo delegado a quem dará as convenientes instruções, remetendome cópia delas.

Essa fonte possibilita entendermos parte do universo das relações de poder nos idos de 1850 em terras do Sul de Mato Grosso, especialmente em Sant'Ana. O domínio do poder privado sob os interesses públicos é uma das questões latentes na correspondência, e

${ }^{41}$ DOC. 106, E. 06 - Registro de Correspondência oficial entre a Província e as Câmaras Municipais, paróquias e bispos. (1849-1852). Arquivo Público do Estado de Mato Grosso, Cuiabá, p. 157. 
em outras fontes arroladas. Novais ${ }^{42}$ ao discutir as condições de privacidade na América Portuguesa, as quais se estenderam por todo o Império, refere-se ao modo como o público e o privado estavam amalgamados desde o início da Colônia, o que contribui para a compreensão do modo como os poderes se instituíam.

Assassinatos e desmandos eram uma constante pela região. Como observado a partir dos documentos analisados, essa questão é fortemente apontada por Leverger, ao tentar colocar um fim no que mais tarde viria a ser chamada de "lei do 44 " ${ }^{43}$ e denunciar as artimanhas de irmãos e sobrinhos de Garcia Leal, no desejo de tomarem o lugar daquele que deveria, sob o entender do presidente da Província, ser extirpado do poder da freguesia.

A correspondência enviada ao Chefe de Polícia da Província, solicitando que se necessário fosse seguisse até Paranaíba, sem ser preciso uma segunda ordem, apresenta o quadro de conflitos dessa localidade, ao contrário do que apontou Justiniano Augusto de Salles Fleury ${ }^{44}$, ao enfatizar que a tranquilidade pública era a marca da região. Essa correspondência também enuncia, de outro lado, a tentativa, por parte das cartas emitidas por alguns moradores, de dar continuidade a essa ordem de coisas, na medida em que o próprio presidente da Província sugere o grau de parentesco entre os que foram indicados para ocupar o lugar de José Garcia Leal, entendendo a proposta como "impróbica e imoral".

\section{ENTRE A VIOLÊNCIA E A RESISTÊNCIA: OS PROCESSOS-CRIME COMO FONTES PRIVILEGIADAS}

Para continuarmos a discutir outras histórias e sujeitos vivendo as adversidades do processo de colonização, mas ao mesmo tempo a elas resistindo, uma informação que nos interessa pode ser encontrada no mapa da população da Província de Mato Grosso ${ }^{45}$, em maio de 1849. No mapa, consta a informação de que na Freguesia de Paranaíba, no ano de 1848, havia cerca de trezentos fogos e a população era constituída de oitocentos livres e quatrocentos escravos, perfazendo um total de mil e duzentos habitantes. Esses dados são significativos para pensarmos o universo de Sant'Ana. Se $30 \%$ da população era composta de escravos, essa relação de trabalho revela-se fundamental para entendermos a região e a história do Sul de Mato Grosso no período imperial. Sob formas variadas - da mão de obra negra ao indígena, escravizado por dívida ou como peão pelas fazendas - a escravidão tornava-se o baluarte das relações de produção e do modo de vida nos campos, arraiais, freguesias e vilas dessa província.

\footnotetext{
${ }^{42}$ NOVAIS, Fernando. Condições de privacidade na Colônia. In: SOUZA, Laura de Mello; NOVAIS, Fernando. História da vida privada no Brasil - cotidiano e vida privada na América Portuguesa. São Paulo: Companhia das Letras, 1997.

${ }^{43}$ CORRÊA, Valmir Batista. Coronéis e bandidos em Mato Grosso (1889-1943). Campo Grande: Editora da UFMS, 1995.

${ }^{44}$ Apud CAMARGO, 2010.

${ }^{45}$ RELATÓRIO do Presidente da Província de Mato-Grosso o Major Doutor Joaquim José de Oliveira na abertura da Assembleia Legislativa Provincial, em 03 de maio de 1849. Rio de Janeiro: Typ. Imp. e Const. de J. Villeneuve e Comp. Rua do Ouvidor, n. 63, 1850. p. 32. Acessado na página http://www.crl.edu/ptbr/brazil/provincial/mato_grosso.
} 
A história das relações de trabalho por essas terras é, pois, semelhante ao que ocorria em outras partes do nosso território. Se o mundo da sociedade e da economia que circundava a vida e trabalho dos povos originários, roceiros e escravos imputava-lhes a violência, a expropriação e a expulsão, não lhes impossibilitava de permanecerem como sujeitos de sua história.

O povoamento de Sant'Ana e de outras localidades, à exceção de Cuiabá, dera-se de maneira dispersa. Pela Província de Mato Grosso, de Norte a Sul, surgiam, nas primeiras décadas do XIX, os núcleos de ocupação que mais tarde seriam denominados freguesias. Junto aos roceiros e proprietários, a figura do escravo também em meio aos processos-crime se fazia presente. Podemos encontrá-los em vários deles, possibilitando entender que as relações amenas e a docilidade, se presentes em um ou outro caso, não podem ser vistas como modelo ou explicativo dessa realidade.

Sobre esse ponto, chamou-nos a atenção um Sumário de Culpa ${ }^{46}$ em que Isaias Joaquim Guimarães figurava como suspeito, a partir de um ofício emitido pelo Chefe de Polícia, Jesuino de Souza Martins, encaminhado à promotoria, solicitando a apuração da morte do escravo Sebastião, em vista do suposto furto de um colar de pouco valor.

$O$ relato de parte das testemunhas arroladas possibilita entender uma trama histórica em que a violência se mostra evidente. Uma das testemunhas, ao ter sido indagada se sabia da morte desse escravo, respondeu que "sabia por ouvir dizer que o escravo Sebastião falecera dos açoites que the mandara dar Isaias Joaquim Guimarães"47. Ressaltamos que a história que se desenrola apresenta os limites da afirmativa das relações harmoniosas entre senhores e escravos nessa província. Isso nos leva a compreender que não é possível afirmar a harmonia no desnudar da violência: o assassínio do escravo pelo senhor. O interessante é observar a solicitação do processo a ser instaurado para apurar esse caso, ainda que o parecer do juiz municipal tenha sido o de não aceitar a denúncia, baseando-se no fato de que não teve testemunhas que pudessem afirmar ser verdade, sem ser "por ouvir dizer".

Na solicitação do processo, ocorrida em março de 1862, foram arroladas cinco testemunhas, dentre elas, proprietários de escravos, como o reverendo Francisco de Sales de Souza Fleury, o negociante Manoel Ferreira Dias, o negociante alferes Antonio Franco de Souza, o também negociante Francisco Anselmo Brito e o lavrador Lucas Antonio da Silva. Como era de se esperar, outros escravos não foram arrolados enquanto testemunhas, dando a entender, pelas profissões enunciadas, certa escolha a quem se deveria dar a palavra.

O ofício emitido pela Justiça pública visando à apuração dos fatos foi considerado improcedente pelo juiz municipal, Joaquim de Oliveira Simões, por entender que

[...] sendo a parte oficial que o delito fora público, todas as testemunhas depuseram vagamente de ouvir dizer; vê-se mais ainda pelo depoimento da terceira e quinta testemunhas que duvidavam ainda mesmo de ouvir dizer o

\footnotetext{
${ }^{46}$ SUMÁRIO de Culpa. 1862 (16 páginas). Paranaíba, Caixa 114/04 - Arquivo do Tribunal de Justiça de Mato Grosso do Sul.

${ }^{47}$ Idem, p. 3.
} 
motivo da morte do escravo, enfim [...] de que o escravo se achava enfermo e em uso de remédios e que o instrumento com que fora castigado não produzia a morte [...]. Sob estes fundamentos o hei despronunciado. ${ }^{48}$

Em agosto de 1862, foi dada essa conclusão, o que sugere a rapidez na resolução do caso, cerca de menos de cinco meses, atendendo aos interesses do senhor de escravos, ao absolvê-lo sem ao menos tê-lo ouvido.

Em um reverso dessa história, encontramos ainda outro processo-crime ${ }^{49}$ que data de 28 de julho de 1863, envolvendo o escravo Geraldo, preso por acusação de ter assassinado Joaquim Barbosa Passos, de vinte anos, filho de seu senhor. Ao impetrar recurso ao Juiz de Direito, por meio de seu procurador, em Miranda, teve a sua absolvição decretada por falta de provas. Desse modo, o procurador conseguiu convencer o juiz da inocência de Geraldo, ao afirmar - com o mesmo argumento utilizado para o caso do escravo Sebastião que "as testemunhas nada valem por só ouvir dizer" e ter sugerido ainda que a vítima, por sua tenra idade, fazia muitos "passeios noturnos", sendo possível que o assassinato fosse cometido "por qualquer um", devido a esses passeios.

Esse processo também é concluído de forma bastante ágil, pois em 3 de dezembro de1863 ocorre o "despronunciamento" do réu, em vista das razões apresentadas pelo recorrente, dando-se então o alvará de soltura ao escravo Geraldo. O desfecho deste processo nos interessa por possibilitar a compreensão de homens e mulheres tecendo suas histórias um tanto a contrapelo ${ }^{50}$, por confrontar-se com a epopeia do pioneiro, dando a entender que, mesmo frente a muitos limites, era possível reivindicar o direito a ter direitos e, em alguns momentos, vê-los reconhecidos.

Outro processo-crime que nos chama a atenção, por tratar da figura dos roceiros, refere-se ao assassinato de José Henriques, em que aparece como acusado Eleutério Paim Pamplona. ${ }^{51} \mathrm{O}$ argumento da contenda parece ter se dado devido ao sumiço de uma égua. Entretanto, no desvelar do processo, percebemos que o caso envolve outras questões que denunciam o universo da pobreza nas fazendas e redondezas de Sant'Ana de Paranaíba. Isso nos faz lembrar o trabalho de Motta, ao analisar a luta dos posseiros "nas fronteiras do poder" público e privado da Província do Rio de Janeiro no século XIX, e apontar a necessidade de o historiador desconfiar das versões oficiais, buscando as entrelinhas da história. $^{52}$

O termo de autuação foi emitido no dia 17 de maio de 1876, na Vila de Sant'Ana de Paranaíba e a denúncia se referia ao fato de que

\footnotetext{
${ }^{48}$ Idem, p. 15.

${ }^{49}$ PROCESSO CRIME. 1863. Caixa 114/07. Paranaíba. Autora: A Justiça Pública; Réu: Eleutério Paim Pamplona. Arquivo do Tribunal de Justiça de Mato Grosso do Sul.

${ }^{50}$ BENJAMIN, Walter. Magia e Técnica, Arte e Política. 3. ${ }^{a}$ ed. São Paulo: Brasiliense, 1987.

51 PROCESSO-CRIME, 1876. Caixa 115/05. Paranaíba. Autora: A Justiça Pública; Réu: Escravo Geraldo. Arquivo do Tribunal de Justiça de Mato Grosso do Sul.

52 MOTTA, Márcia Maria Menendes. Nas fronteiras do poder - conflito e direito à terra no Brasil do século XIX. Rio de Janeiro: Vício de Leitura; Arquivo Público do Estado do Rio de Janeiro, 1998.
} 
em dias do ano de 1869, na Fazenda de Santa Fé, estando José Henrique de Tal em sua casa, foi aí assassinado pelo denunciado Eleutério Paim Pamplona, ignorando a Promotoria se a tiros ou facadas e se de frente ou de emboscada, por quanto, como se veja já decorreram-se cerca de cinco anos, e nenhum esclarecimento se encontra a tal suspeito nos cartórios criminais desta Vila.

José Joaquim Faria, Adriano Pereira Borges, Manoel Felizardo, José Manoel Barbudo, Manoel Vicente Cruz, Jerônimo Vicente Cruz e José de Tal (por apelido Juca Preto) foram arrolados como testemunhas para o processo. O primeiro a dar o seu depoimento foi Adriano Pereira Borges, de quarenta e oito anos, lavrador, casado e natural da Província de Minas, morador na Vila. Conforme esta testemunha, pelo que ouvira dizer e o que contara Ana Henriques, esposa do falecido, "o assassinato se dera de emboscada, de dia e um pouco retirado da casa de José Henrique em ocasião que este vinha da roça, caindo instantaneamente por efeito de dois tiros de espingarda ou garrucha carregada com bala". Indagada a testemunha pela razão e fundamento da morte, observou que "Eleutério Paim Pamplona e José Henriques eram inimigos em consequência do negócio de uma égua que este tomara a força daquele".

Manoel Jerônimo da Costa, conhecido como Manoel Felizardo, a segunda testemunha, de quarenta anos, lavrador, casado, natural da Província de São Paulo e morador em Paranaíba, sendo questionado sobre o fato, narrou

que não viu, mas que ouvira da própria boca de Eleutério Paim Pamplona que ele assassinara a José Henriques pelas razões e maneira seguintes: Havia entre eles uma sociedade em uma roça de milho, depois convencionaram-se de ficar um só senhor da mesma, e Eleutério vendera à José Henriques a sua parte recebendo em pagamento uma égua e porque a criação destruísse a roça, José Henriques entendeu que não devia de sofrer prejuízo, então assenhoreou-se novamente da égua sem consentimento de seu dono, passado alguns dias Eleutério esperou a José Henriques no caminho da roça perto da casa deste para o que abrira uma picada no mato, afim de conservar-se oculto, e aí depois de ter passado a mãe e um filho menor que moravam em companhia de Henrique, recebeu este um tiro de espingarda que partia do meio das florestas, de um lado do caminho, então caindo José Henriques por terra e aí veio o seu assassino Eleutério, e lhe perguntou se lhe perdoava o crime, ao que respondeu o infeliz que sim, cobriu o rosto com as duas mãos e pediu-lhe que não repetisse a carga, ao que disse Eleutério: que então tome lá outros, e disparou-lhe novo tiro que acertou sobre o pescoço, que produziu-lhe a morte instantaneamente.

Jerônimo Ferreira da Cruz, por apelido Jerônimo Vicente, de vinte e nove anos de idade, casado, lavrador e natural de Paranaíba, foi a terceira testemunha. Informou em seu relato ser cunhado de Eleutério Paim Pamplona e que na ocasião do fato vivia na Província de Minas Gerais, nada sabendo, pois "as notícias vagam pela própria boca de Eleutério".

A quarta testemunha, José Antonio Bernardes, conhecido como Juca Preto, lavrador, casado, natural da Província de São Paulo e morador em Sant'Ana de Paranaíba, contou que 
[...] não viu, mas que ouviu do próprio Eleutério que ele fora o autor do assassinato perpetrado na pessoa de José Henrique pelas razões seguintes: José Henrique comprara de Eleutério uma roça de milho que pagara com uma égua, e porque esta roça se destruísse pelos estragos feitos pela criação o comprador, entendeu não haver prendê-la assenhoreando-se da dita égua que conservava oculta, por este fato tornaram-se inimigos, e passado algum tempo Eleutério assassinou José Henriques, esperando-o para este fim de emboscada no caminho da roça, tendo este feito de propósito uma picada na mata, que José Henriques estava na roça com uma mulher e um menino, colhendo, digo, plantando arroz, nisto vem uma chuva e a mulher com um menino procuraram a casa, entretanto aumentou-se esta chuva e José Henriques resolveu recolher-se igualmente para a sua casa e no caminho recebeu um tiro de espingarda expedido da mata e aí caiu. Eleutério chegou-se a ele e conversaram bastante tempo e finalmente perguntou ao infeliz se ele perdoa a sua morte, ao que este respondeu que sim, e que não o acabasse de matar: a isto Eleutério disparou-Ihe outro tiro que acertou-lhe sobre o pescoço e que produziu-lhe a morte instantaneamente. Consumado isto Eleutério virou o corpo de bruço e seguiu em direitura à casa do defunto, aí chegando chamou por um filho deste e ordenou-lhe que lhe fosse mostrar aonde estava a já referida égua, o que cumpriu. $O$ menor dirigiu-se com Eleutério à capoeira onde a mesma se achava, e aí Eleutério pegou-a e com ela retirou-se deixando primeiro o menino em casa. Acrescentou a testemunha que tudo isto ouviu do próprio Eleutério alguns meses depois.

Em vista da demora para a instauração do processo, ou seja, cerca de cinco anos do fato, foram inquiridas novas testemunhas. Manoel Dionizio Ferreira, de vinte e cinco anos, foi a quinta testemunha. Solteiro, natural e morador de Paranaíba, narrou que "sabia por ouvir do próprio Eleutério Paim Pamplona que ele havia assassinado José Henriques de Tal, no lugar denominado Boa Vista, pertencente a fazenda Santa Fé". Observou ainda que também ouviu de sua mãe, Felisberta Maria de Jesus, e de Florentino de Oliveira Simões, que eles haviam dado sepultura ao corpo de José Henriques.

Felisberta Maria de Jesus, de cinquenta anos, lavradora, natural de São Paulo e moradora em Sant'Ana de Paranaíba, foi a sexta testemunha. Indagada sobre o fato, contou que Ana, esposa de José Henriques, fora em sua casa logo após o assassinato, pedindo-lhe que "fosse dar sepultura ao corpo". Ela, então "mandou por dois meninos que fossem chamar o vizinho, Florentino de Oliveira Simões, para abrir a sepultura, o qual só apareceu no dia seguinte", daí ter feito o enterro ao corpo.

Como sétima testemunha do processo, Florentino de Oliveira Simões, de trinta e seis anos, lavrador, casado, natural de Sant'Ana de Paranaíba, respondeu que foi chamado em sua casa por Dona Felisberta, viúva de Manoel Vicente, para ajudar a dar sepultura a José Henriques, assassinado por dois tiros. Seu depoimento traz as mesmas informações que os demais, diferindo apenas nos detalhes da narração do assassinato.

As duas últimas testemunhas, José Manoel da Silva, de sessenta anos de idade, natural de São Paulo, e José de Farias e Souza, de quarenta e quatro anos, da mesma província, narraram, de forma sucinta, informações similares aos demais depoentes. Como conclusão do processo, quatro anos após, em 1880, houve a orientação de que, por libelo crime acusatório, "pede-se a condenação do réu Eleutério Paim Pamplona, no grau máximo 
do art. 192 do Código Penal [...]". Mas, não houve um desfecho no processo, "por não se constituir júri e por Eleotério estar ausente dos Termos da Vila".

\section{ALGUMAS CONSIDERAÇÕES}

O processo-crime envolvendo a morte de José Henriques, caso seja visto sob a aparência, esconderia a sua essência, ou seja, as agruras vividas cotidianamente por homens e mulheres pobres. As pequenas roças e criações, em sua maior parte, estavam incrustadas em meio às grandes e médias propriedades, já desvelando a presença do agregado e do posseiro vivendo os limites dessa condição. As relações conflituosas materializavam-se, então, no dia a dia desses sujeitos, em contendas entre compadres, parentes, vizinhos, muitas vezes não chegando a afetar o dono da fazenda.

Os casos de Sebastião e de Geraldo evidenciam duas histórias que se assemelham por envolverem escravos, mas ao mesmo tempo diferem, já que uma é de expressa violência; outra de conquista da liberdade. São faces da história de Sant'Ana de Paranaíba. Há outros casos em que povos originários figuram nos processos-crime, como testemunhas, réus ou vítimas, mas não fora o objetivo deste texto apresentá-los, e sim apontar indícios dessa presença.

Desde as monções, foi possível encontrar as marcas dos pobres livres e escravos pelo Sul de Mato Grosso. Também os povos originários despontaram por esses caminhos ao longo de todo o século XVIII e XIX. As Notícias Práticas e o Relato de viagem de Francisco José de Lacerda Almeida, referentes aos sujeitos e percursos no contexto das monções, possibilitaram olhar para o modo como a administração pública e os interesses privados se utilizavam dos negros da terra e escravizados por esses caminhos, tal como de pobres livres. Os roceiros aparecem nos relatos dos viajantes e presidentes da Província, em um ou outro momento, enunciando, quase sempre, a dificuldade em permanecerem na terra, principalmente pela resistência indígena ao estabelecimento de fogos pelo seu território. É possível acrescentar que também pela concentração da terra nas mãos de alguns poucos.

Os povos originários Paiaguá, Guaicuru e Cayapó, entre outros, impregnam as fontes, possibilitando que vejamos o quanto defenderam o seu território da ocupação do não índio, ainda que, em sua maior parte, tenham sentido o peso da "civilização e da catequese".

Em vista das histórias monçoeiras e do que se segue, é possível afirmar que temos nessa região, assim como em toda a América Portuguesa e Império, muito mais séculos de escravidão do que de liberdade, muito mais o domínio dos interesses privados na defesa do latifúndio do que o direito ao plantio de alimentos pelas pequenas roças.

Essas são questões que requerem uma análise mais aprofundada, na perspectiva de uma "história vista de baixo" ${ }^{53}$. As análises aqui apresentadas buscaram dar os primeiros

\footnotetext{
${ }^{53}$ THOMPSON, Edward P. A miséria da teoria ou um planetário de erros. Rio de Janeiro: Zahar Editores, 1981. SHARPE, Jim. A história vista de baixo. In: BURKE, Peter (Orgs). A escrita da história: novas perspectivas. São Paulo: Editora UNESP, 1992.
} 
passos na procura dos roceiros, escravos e povos originários pelos campos do Sul de Mato Grosso, sem perder de vista os detentores do poder econômico e político da região de Paranaíba.

Homens e mulheres, donos de escravos, para se manterem, fundamentavam-se, como observou Moura ${ }^{54}$, no trabalho escravizado e livre, de pobres da terra e povos originários, que fizeram a fortuna de alguns poucos, revelando a miséria de muitos outros. Isso, todavia, não esconde as outras histórias, tecidas a duras penas, num lugar que foi muito mais do que o "sertão dos Garcias", como denominado pelos memorialistas. Um sertão da gente pobre, escravizada e livre, que precisa ser redescoberto para que a história do pioneiro não acoberte a da gente comum.

O contato com as fontes, particularmente com os processos-crime, nos mostraram a existência de roceiros e os conflitos latentes, por vezes, no interior das próprias roças. A partir da análise das fontes sobre as relações de poder em Paranaíba, entendemos como esses enfrentamentos ultrapassavam os limites das roças, ao evidenciar o poder do mando e desmando na região.

O olhar se centrou em Sant'Ana de Paranaíba e seus arredores, mas se quiséssemos poderíamos estendê-lo a várias localidades dessas terras distantes da capital do Império. Se a distância do centro de decisões políticas e econômicas se apresentava geograficamente, o mesmo não se pode dizer da vivência entre senhores, escravos, pobres livres e povos originários, bastante similares a outros rincões do Império.

Os casos apresentados nos processos-crime mostram o universo de violência, tanto por parte do senhor como por parte do roceiro, a exemplo da ação de Eleutério. Todavia, explicitam a presença incômoda de roceiros, escravos e indígenas nas malhas de uma sociedade em que a terra e a liberdade eram cerceadas (e continuam a ser) aos pobres dos campos e cidades, apontando, então, os limites do arbítrio, mas também o seu reverso.

Recebido em 05/08/2012

Aceito para publicação em 01/10/2012

\footnotetext{
${ }^{54}$ MOURA, Zilda A. Cativos nas terras dos Pantanais: escravidão e resistência no sul de Mato Grosso - séculos XVIII e XIX. Passo Fundo: Ed. UPF, 2008.
} 